Research Article

\title{
A study to assess the effect of vitamin D supplementation on insulin resistance and glycaemic control in type 2 diabetes mellitus patients
}

\author{
Parminder K. Dhillon ${ }^{1}$, Jaswant Rai ${ }^{1}$, B. S. Bal ${ }^{2}$, Navyug R. Singh ${ }^{1}$
}

\begin{abstract}
${ }^{1}$ Department of Pharmacology, Government Medical College, Amritsar, Punjab, India, ${ }^{2}$ Department of Medicine, Government Medical College, Amritsar, Punjab, India
\end{abstract}

Received: 28 January 2016 Accepted: 02 March 2016

\section{*Correspondence to: \\ Dr. Parminder K. Dhillon, Email: drdhillonparminder@ gmail.com}

Copyright: (C) the author(s), publisher and licensee Medip Academy. This is an openaccess article distributed under the terms of the Creative Commons Attribution NonCommercial License, which permits unrestricted noncommercial use, distribution, and reproduction in any medium, provided the original work is properly cited.

\begin{abstract}
Background: Type 2 Diabetes Mellitus is highly prevalent worldwide and its intensive control with available pharmacological agents is usually hampered due to numerous side-effects as well as resistance to the therapy. Recent research suggests that vitamin D supplementation ameliorates glycaemic burden and effectively reduces the risk and progression of type 2 diabetes. So, present study was done to assess the effect of vitamin D supplementation on glycaemic control and insulin resistance in type 2 diabetic patients.

Methods: A Prospective Randomized Parallel Open-label study of three months duration was conducted on 60 type 2 diabetes mellitus patients, who were divided into two groups (group A and B) of 30 patients each. Group A received standard oral hypoglycaemic agents and $600000 \mathrm{IU}$ of intramuscular injection of vitamin D3 for 3 doses one month apart, while the Group B received only standard oral hypoglycaemic agents. Subjects were evaluated for fasting blood glucose, HbA1c, serum insulin levels, insulin resistance and serum vitamin D levels at defined intervals.

Results: The results showed a significant improvement in fasting blood glucose in both the groups during the study period (group A $p<0.004$, group $B \mathrm{p}<0.03$ ), however no significant difference was observed between the two groups $(p<0.7)$ at the end of 12 weeks. There was a significant decrease in HbA1c $(p<0.04)$, serum insulin levels $(\mathrm{p}<0.04)$ and HOMA-IR $(\mathrm{p}<0.03)$ in group A compared with group B.

Conclusions: The study showed that vitamin D supplementation improves the glycaemic control and insulin sensitivity in type 2 diabetes mellitus patients.
\end{abstract}

Keywords: Vitamin D, Type 2 diabetes mellitus, Vitamin D deficiency, Glycaemic control, Insulin resistance

\section{INTRODUCTION}

The prevalence of diabetes is rapidly rising with more than $80 \%$ of diabetic deaths occurring in low-income and middle-income countries, affecting the youth and middle aged population also in addition to the elderly. According to diabetes atlas published by the International Diabetes Federation (IDF), 382 million people had diabetes in 2013 and this number is expected to rise to 592 million by $2035 .{ }^{1}$ India at present has the world's largest diabetic population. As per ICMR-INDIAB national study, there were 62.4 million people with type 2 diabetes and 77 million people with pre-diabetes in India which is projected to increase to 101 million by the year $2030 .^{2}$
The predominant features in type 2 Diabetes Mellitus (DM) are $\beta$-cell dysfunction and insulin resistance at the level of muscle, fat and liver. Insulin resistance (IR) is defined as a condition when normal amount of insulin in body fails to produce the desired response. Insulin sensitivity is a quantifiable parameter that is measured as the amount of glucose cleared from the blood in response to a dose of insulin. ${ }^{3}$

Type 2 DM can be managed using non- pharmacological (diet control, exercise etc.) and pharmacological (sulfonylureas, meglitinides, biguanides, thiozolidinediones, insulin etc.) measures. These conventional anti-diabetic drugs can effectively reduce HbA1c levels, but intensive control with these agents is usually hampered by side effects such as hypoglycaemia, 
weight gain etc. Moreover, newer anti-diabetic drugs (such as incretin analogs, amylin mimetic, SGLT-2 inhibitors) are expensive, with little information on their long term safety. So there is a need to develop new treatment options in order to achieve the glycaemic control with less undue side effects. Vitamin D supplementation is a new strategy which has been reported in some global studies to play an important role in normal insulin secretion in response to glucose and in effectively reducing the risk and progression of type 2 DM and insulin resistance. ${ }^{4,5}$

Vitamin D, apart from its role in bone metabolism has got a pleiotropic effect in the pathogenesis of many diseases such as cancer, cardiovascular diseases and diabetes. ${ }^{6}$ Recently, interest in vitamin D and diabetes emerged from many animal and human studies which identified vitamin D receptors (VDRs) on pancreatic tissue. ${ }^{7}$ These studies also demonstrated that diabetic patients have lower levels of vitamin $\mathrm{D}$ and insulin resistance was found to be more prevalent in vitamin $\mathrm{D}$ deficient patients. So, in order to see these pleiotropic effects, optimal serum vitamin D levels have to be maintained adequately. The general consensus is that vitamin D sufficiency is achieved, when vitamin D serum levels are 30-32 ng/ml. Vitamin D deficiency is defined as serum levels of $<20 \mathrm{ng} / \mathrm{ml}$ and vitamin D insufficiency is defined as serum levels ranging from 20-29 ng/ml. An overall safe range for vitamin $\mathrm{D}$ for most of the known effects of vitamin D is $30-100 \mathrm{ng} / \mathrm{ml}^{8}$

At present, literature regarding vitamin D status in type 2 diabetes is scarce and conflicting. Many observational studies have shown that restoration of vitamin D levels ameliorate glucose tolerance and improve insulin response in diabetic patients with vitamin D deficiency. ${ }^{9,10}$ While the results of interventional studies done so far in this field have been inconsistent. ${ }^{11-13}$ This discrepancy might be related to difference in race, dosage or formulation of vitamin D used and sample size. Moreover, very few studies have been conducted in north Indian population. So the present study aims at assessment of effect of vitamin D supplementation on insulin sensitivity, short and long term glycaemic control in type 2 diabetes mellitus patients.

\section{METHODS}

\section{T Study design}

It was a prospective, randomized open label parallel group study, conducted in department of Pharmacology (Government Medical College, Amritsar) after obtaining the approval of the institutional thesis committee and ethics committee. Sixty patients diagnosed with type 2 diabetes were recruited from the Medicine out-patient department of Guru Nanak Dev Hospital, Amritsar for the duration of 12 weeks. Patients fulfilling the inclusion criteria were informed regarding the study in vernacular language and a written informed consent was taken from them.

\section{Inclusion criteria}

Patients in the age group of 20-70 years (either sex) with diagnosis of type 2 diabetes mellitus, fasting glucose levels $\geq 126 \mathrm{mg} / \mathrm{dl}$ and $\mathrm{HbA} 1 \mathrm{c}$ levels $\geq 6.5 \%$.

\section{Exclusion criteria}

Patients with pre-existing hepatic and renal disease, uncontrolled blood pressure or any other serious major illness, patients on drugs which interact with vitamin D, with history of recent consumption of vitamin $D$, pregnant and lactating women, patients with history of type 1 diabetes mellitus and insulin therapy, were excluded from the study.

\section{Intervention}

Sixty patients fulfilling the inclusion criteria were enrolled and randomized using computer generated randomisation code in two groups: group A and group B of 30 patients each. Group A received standard oral hypoglycaemic agents (OHAs) and 600000 IU of intramuscular injection of vitamin D3 for 3 doses one month apart. Group B received only standard OHAs. After detailed history and clinical examination, routine investigations were carried out in Department of Pharmacology, Department of Microbiology and Computerized Clinical Biochemistry Laboratory of Guru Nanak Dev Hospital as follows: (a) fasting blood sugar (FBG by glucose-oxidase method) ${ }^{14,15}$ every 2 weeks (b) $\mathrm{HbA1} \mathrm{c}^{16,17}$ (cation-exchange resin method), serum insulin $^{18-20}$ (DRG Insulin ELISA kit), serum vitamin $D^{21-}$ ${ }^{23}$ (Calbiotech Vitamin D ELISA kit) levels and HOMA$\mathrm{IR}^{24}$ (Homeostatic model assessment to quantify Insulin resistance $=\mathrm{S}$. Insulin $\times \mathrm{S}$. Glucose/405) at baseline and at 12 weeks. Apart from these serum calcium, serum phosphorus, ALP (alkaline phosphatase), LFTs (liver function tests) were also done to monitor vitamin D toxicity.

\section{Follow up}

The patient visits were scheduled in the morning with 12 hours of fasting. At each follow up: (a) history of adverse events related to vitamin D toxicity (nausea, vomiting, abdominal pain, constipation, major hypoglycaemic event or other relevant complaints) was taken (b) blood samples were taken for requisite investigations as per schedule.

\section{Statistical analysis}

It was performed using Graphpad instat 3. The observations were tabulated in the form of mean \pm standard deviation and analysed using ' $t$ ' test. The paired t-test was used for intra-group comparison and unpaired t-test for intergroup comparison. The level of significance was determined as its ' $p$ ' value with $p>0.05$-insignificant, $\mathrm{p}<0.05$-significant, $\mathrm{p}<0.01$-very significant and $\mathrm{p}<0.001$ highly significant. 


\section{RESULTS}

Sixty patients (23 males and 37 females) completed the study period of 12 weeks. The demographic characteristics were comparable in two groups at the beginning of the study $(\mathrm{p}>0.05)$. The mean age of patients in two groups at baseline was found to be comparable which came around to be $52.4 \pm 11.03$ years in group A and 49.6 \pm 10.47 years in group B. (Table 1).

Table 1: Baseline parameters of study patients.

\begin{tabular}{|lll|}
\hline Parameter & Group A & Group B \\
\hline Age (years) & $52.4 \pm 11.03$ & $49.6 \pm 10.47$ \\
\hline No. of pts. & 30 & 30 \\
\hline HbA1c $(\%)$ & $8.5 \pm 1.03$ & $8.3 \pm 1.08$ \\
\hline FBG $(\mathrm{mg} / \mathrm{dl})$ & $162 \pm 25.22$ & $163.3 \pm 38.79$ \\
\hline FSI $(\mu \mathrm{IU} / \mathrm{ml})$ & $26.1 \pm 15.81$ & $26.2 \pm 10.23$ \\
\hline HOMA-IR & $10.6 \pm 7.18$ & $10.7 \pm 5.14$ \\
\hline S. vitamin D $(\mathrm{ng} / \mathrm{ml})$ & $24.7 \pm 8.14$ & $28.7 \pm 11.99$ \\
\hline S. calcium $(\mathrm{mg} / \mathrm{dl})$ & $8.2 \pm 0.78$ & $8.7 \pm 1.12$ \\
\hline S. phosphorus $(\mathrm{mg} / \mathrm{dl})$ & $3.4 \pm 0.98$ & $3.5 \pm 0.59$ \\
\hline ALP $(\mathrm{IU} / \mathrm{L})$ & $59.1 \pm 26.29$ & $57.9 \pm 15.29$ \\
\hline SGOT(IU/L) & $39.5 \pm 9.2$ & $37.6 \pm 12.94$ \\
\hline SGPT(IU/L) & $48.6 \pm 13.25$ & $44.2 \pm 11.2$ \\
\hline
\end{tabular}

Study parameters of both the groups at 0 week (Mean \pm SD) were comparable with no significant difference between two groups ( $\mathrm{p}>0.05)$.

(HbA1c-glycosylated haemoglobin, FBG-Fasting Blood Glucose, FSI-Fasting Serum Insulin, HOMA-IR - Homeostatic Model of Assessment for Insulin Resistance, ALP- Alkaline phosphatase, SGOT-Serum Glutamic Oxaloacetic Transaminase and SGPT-Serum Glutamic Pyruvic Transaminase).

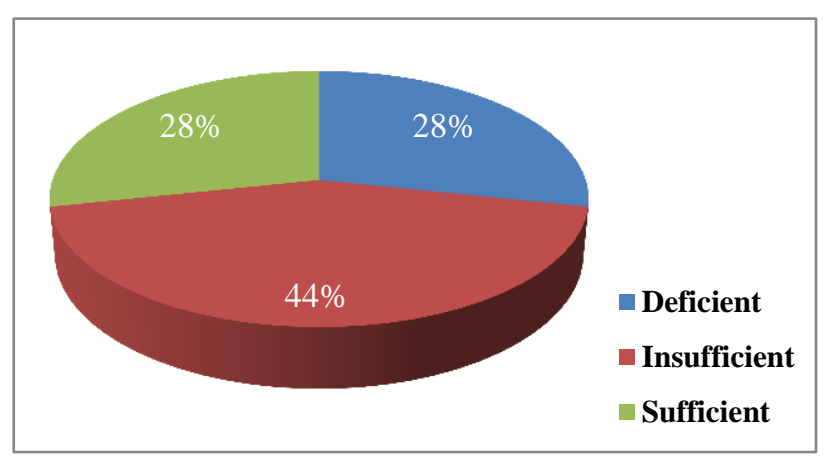

(Sufficient- serum vitamin D levels $>30 \mathrm{ng} / \mathrm{ml}$, Insufficientserum vitamin D levels 20-29 $\mathrm{ng} / \mathrm{ml}$, Deficient- serum vitamin D levels $<20 \mathrm{ng} / \mathrm{ml}$ )

\section{Figure 1: Baseline vitamin D status of study patients.}

It was observed that vitamin D deficiency/insufficiency was prevalent in $71.6 \%$ of total patients recruited in the study. Number of patients having vitamin D level $<20 \mathrm{ng} / \mathrm{ml}$ (vitamin D deficient) were 17 and those with vitamin D level ranging from 20-29ng/ml (vitamin D insufficient) were 26 in total out of 60 patients enrolled in study (Figure 1).
A significant reduction in FBG was observed at 2 weeks, 4 weeks, 6 weeks, 8 weeks, 10 weeks and 12 weeks in both group A and group B. Group A showed a slightly greater reduction in the FBG levels compared to group B although this difference was statistically non-significant (Figure 2).

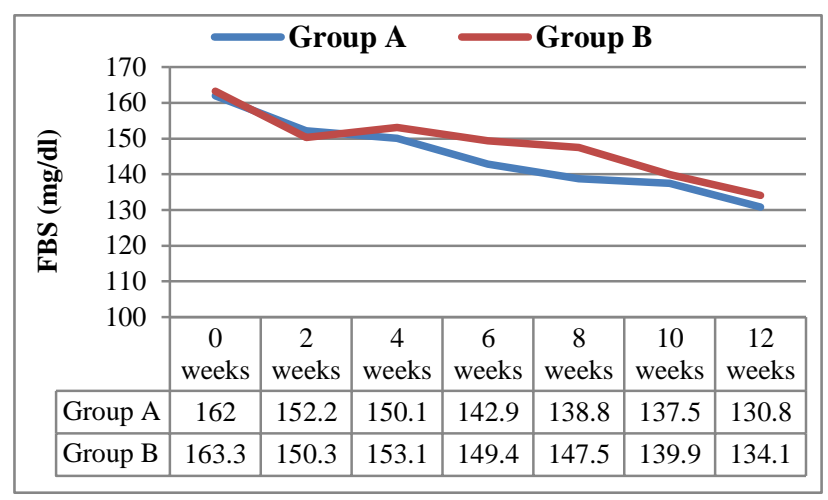

Figure 2: Progressive change in fasting blood glucose (FBG) over 12 weeks.

At the end of 12 weeks, there was a significant decrease in HbA1c levels $(p<0.01)$, fasting serum insulin $(p<0.02)$ and HOMA-IR $(\mathrm{p}<0.003)$ in group A. On the other hand in group $B$, there was a non-significant $(p>0.05)$ increase in HbA1c levels, fasting serum insulin levels and a nonsignificant $(\mathrm{p}>0.05)$ decrease in HOMA-IR (Table 2).

Table 2: Change in glycaemic control and insulin resistance (mean \pm S.D) over 12 weeks.

\begin{tabular}{|c|c|c|c|c|}
\hline Parameter & $\begin{array}{l}\text { Time } \\
\text { period }\end{array}$ & $\begin{array}{l}\text { Group } \\
\text { A }\end{array}$ & $\begin{array}{l}\text { Group } \\
\text { B }\end{array}$ & p value \\
\hline \multirow{3}{*}{$\mathrm{HbA} 1 \mathrm{c}$} & 0 week & $\begin{array}{l}8.5 \pm \\
1.03\end{array}$ & $\begin{array}{l}8.3 \pm \\
1.08\end{array}$ & \\
\hline & 12 week & $\begin{array}{l}7.9 \pm \\
1.23\end{array}$ & $\begin{array}{l}8.6 \pm \\
1.5\end{array}$ & $<0.05$ \\
\hline & $\mathrm{p}$ value & 0.016 & 0.054 & \\
\hline \multirow{3}{*}{ FSI } & 0 week & $\begin{array}{l}26.1 \pm \\
15.81\end{array}$ & $\begin{array}{l}26.2 \pm \\
10.23\end{array}$ & \\
\hline & 12 week & $\begin{array}{l}21.4 \pm \\
13.78\end{array}$ & $\begin{array}{l}28.5 \pm \\
12.62\end{array}$ & $<0.05$ \\
\hline & $\mathrm{p}$ value & 0.024 & 0.308 & \\
\hline \multirow{3}{*}{ HOMA-IR } & 0 week & $\begin{array}{l}10.6 \pm \\
7.18\end{array}$ & $\begin{array}{l}10.7 \pm \\
5.14\end{array}$ & \\
\hline & 12 week & $\begin{array}{l}6.9 \pm \\
4.84\end{array}$ & $\begin{array}{l}9.7 \pm \\
4.94\end{array}$ & $<0.05$ \\
\hline & $\mathrm{p}$ value & 0.0003 & 0.2396 & \\
\hline
\end{tabular}

A subgroup analysis was done at the end of 12 weeks in which group A showed a significant mean percentage reduction in $\mathrm{HbA} 1 \mathrm{c}$ and HOMA-IR levels. On the other hand in group B vitamin 'deficient' and 'insufficient' subgroup of patients showed mean percentage increase in $\mathrm{HbA1c}$ levels. Also, the mean percentage reduction in HOMA-IR in vitamin D 'deficient' (-4.2\%), 'insufficient' $(-10 \%)$ and 'sufficient' $(-13.7 \%)$ subgroups was very less 
compared to group A (vitamin D 'deficient'-36\%, 'insufficient'-34.4\% and 'sufficient'-32\% subgroups). Group A showed a more favourable effect in terms of mean percentage reduction in $\mathrm{HbA} 1 \mathrm{c}$ and HOMA-IR compared to group $\mathrm{B}$. This shows that adequate serum vitamin D levels are associated with good glycaemic control and better reduction in insulin resistance (Table 3).

Table 3: The effects vitamin D supplementation on HbA1c and HOMA-IR (\% age change) at different baseline vitamin $D$ levels.

\begin{tabular}{|c|c|c|c|}
\hline Group A & $\begin{array}{l}\text { Vitamin D } \\
\text { deficient } \\
\text { patients }\end{array}$ & $\begin{array}{l}\text { Vitamin D } \\
\text { insufficient } \\
\text { patients }\end{array}$ & $\begin{array}{l}\text { Vitamin D } \\
\text { sufficient } \\
\text { patients }\end{array}$ \\
\hline $\begin{array}{l}\text { Number of } \\
\text { patients }\end{array}$ & 8 & 14 & 8 \\
\hline $\begin{array}{l}\text { \%age } \\
\text { change in } \\
\text { HbA1c }\end{array}$ & $-11.7 \%$ & $-5.6 \%$ & $-5 \%$ \\
\hline $\begin{array}{l}\text { \%age } \\
\text { change in } \\
\text { HOMA-IR }\end{array}$ & $-36 \%$ & $-34.4 \%$ & $-32.5 \%$ \\
\hline Group B & $\begin{array}{l}\text { Vitamin D } \\
\text { deficient } \\
\text { patients }\end{array}$ & $\begin{array}{l}\text { Vitamin D } \\
\text { insufficient } \\
\text { patients }\end{array}$ & $\begin{array}{l}\text { Vitamin D } \\
\text { sufficient } \\
\text { patients }\end{array}$ \\
\hline $\begin{array}{l}\text { Number of } \\
\text { patients }\end{array}$ & 9 & 12 & 9 \\
\hline $\begin{array}{l}\text { \%age } \\
\text { change in } \\
\text { HbAlc }\end{array}$ & $+6.9 \%$ & $+4.1 \%$ & $-0.5 \%$ \\
\hline $\begin{array}{l}\text { \%age } \\
\text { change in } \\
\text { HOMA-IR }\end{array}$ & $-4.2 \%$ & $-10 \%$ & $-13.7 \%$ \\
\hline
\end{tabular}

('+' increase and '-' decrease)

Table 4: Effect of vitamin D supplementation on routine investigations $($ mean \pm S.D) has done to monitor vitamin $D$ toxicity at 12 weeks.

\begin{tabular}{|llll|}
\hline Parameters & Group A & Group B & p-value \\
\hline $\begin{array}{l}\text { S. vitamin D } \\
\text { (ng/ml) }\end{array}$ & $47.1 \pm 14.77$ & $31.1 \pm 15.44$ & 0.0001 \\
\hline $\begin{array}{l}\text { S. calcium } \\
\text { (mg/dl) }\end{array}$ & $9.1 \pm 1.14$ & $8.5 \pm 0.60$ & 0.0073 \\
\hline $\begin{array}{l}\text { S. phosphorus } \\
\text { (mg/dl) }\end{array}$ & $3.5 \pm 1.14$ & $3.4 \pm 0.72$ & 0.6977 \\
\hline ALP (IU/L) & $69.3 \pm 26.28$ & $55.5 \pm 10.96$ & 0.0101 \\
\hline SGOT(IU/L) & $40.4 \pm 11.18$ & $38 \pm 7.99$ & 0.3299 \\
\hline SGPT(IU/L) & $47.3 \pm 12.81$ & $45.9 \pm 9.5$ & 0.6327 \\
\hline
\end{tabular}

The mean percentage increase in serum vitamin $D$ levels was extremely significant in group A $(p<0.0001)$ in comparison to group B $(\mathrm{p}>0.05)$. There was also a significant increase in serum calcium and ALP (alkaline phosphatase) levels in group A compared to group B, but the levels were within the normal limits. Rest of the parameters were comparable. The patients of both the groups under study tolerated the drugs well and in none of the patients the adverse effects were serious enough to discontinue the drug therapy (Table 4).

\section{DISCUSSION}

The present study was conducted between the periods of July 2014 to September 2015. Sixty type 2 diabetic patients were recruited in the study and randomized into two groups of thirty patients each. Group A was assigned with a combination of standard oral hypoglycaemic agents and 600000 IU of intramuscular injection of vitamin $\mathrm{D}_{3}$ for 3 doses one month apart and group $\mathrm{B}$ received only standard oral hypoglycaemic agents. The primary objective of study was to evaluate the effect of vitamin D supplementation therapy on glycaemic control, insulin levels and insulin resistance after 12 weeks of treatment.

After 3 months of study period, a significant reduction in FBG was observed every 2 weeks in both group A and group B. An extremely significant $(\mathrm{p}<0.0001)$ decrease of $19.2 \%$ with mean reduction of $31.2 \mathrm{mg} / \mathrm{dl}$ in FBG levels was observed in group A. Similar extremely significant ( $p<0.0001$ ) reduction of $17.8 \%$ with mean change of 29.1 $\mathrm{mg} / \mathrm{dl}$ in $\mathrm{FBG}$ was seen in group B. A randomized placebo-controlled trial conducted by Asema, et al with 6 weeks of vitamin D supplementation only, has also reported a significant reduction in FBG $(-0.89 \pm 0.69$ vs + $0.26 \pm 0.92 \mathrm{mmol} / \mathrm{l}, \mathrm{p}<0.001) .{ }^{25}$ Mohamad, et al also found significant decrease in FBG levels after 2 months of vitamin D supplementation. ${ }^{26}$ However in the present study vitamin D therapy as such does not seem to play any additive role as far as effect on FBG levels is concerned. Results of this study were contrary to the randomized double-blind clinical trial conducted on 87 vitamin D-deficient type 2 diabetic patients by Sadiya, et al which showed no significant change in FBG compared with baseline in either group. ${ }^{27}$

A statistically significant $(\mathrm{p}=0.01)$ reduction in the levels of $\mathrm{HbA} 1 \mathrm{c}$ were observed within group A with a mean percentage fall of $6.9 \%$. Group $\mathrm{B}$ exhibited a nonsignificant $(p>0.05)$ rise of $3.5 \%$ in HbA1c levels. There was a significant $(p<0.05)$ difference between the two groups in terms of HbA1c values attained at the end of 12 weeks of treatment. The results were similar to a parallel designed randomized placebo-controlled clinical trial, conducted by Tabesh, et al which reported reduced HbA1c levels (change from baseline of $-0.70 \pm 0.19 \%, p=$ 0.02 ) with vitamin D supplementation. ${ }^{28}$ Another crosssectional study by Bonakdaran, et al done with 119 type 2 diabetic patients showed that calcitriol therapy resulted in significant reduction in HbAlc levels $(-0.8 \%, \mathrm{p}=0.01){ }^{29}$ Similarly, a study was done by Hamid, et al to evaluate the effect of adding vitamin D to therapeutic regimen of type 2 diabetic patients compared to placebo. It also showed significant reduction in HbA1c levels $(-0.8 \%$, $\mathrm{p}=0.006){ }^{30}$ 
At the end of 12 weeks, there was a significant decrease in fasting serum insulin (FSI) levels $(p=0.02)$ and HOMA-IR ( $\mathrm{p}=0.003$ ) with a mean percent change of 17.9 $\%$ and $34.9 \%$ respectively in group A. On the other hand, in group B, there was a non-significant increase in fasting serum insulin levels $(\mathrm{p}=0.3)$ and a non-significant decrease in HOMA-IR $(\mathrm{p}=0.2)$ with mean percent change of $8.3 \%$ and $9.3 \%$ respectively. Significant inter group difference $(\mathrm{p}<0.05)$ was observed between group A and B in the levels of FSI and HOMA-IR at the end of 12 weeks. HOMA-IR is a valid epidemiological tool to quantify insulin resistance. Since, insulin sensitivity is inversely proportional to insulin resistance, significant reduction in HOMA-IR levels in group A suggests improved insulin sensitivity in this group of patients compared to group B. These findings were consistent with a study done by Afsaneh, et al on 100 diabetic patients. This study also showed a significant reduction in fasting insulin levels $(\mathrm{p}=0.02)$ with a mean change of 20 $\%$ and HOMA-IR $(\mathrm{p}=0.008)$ with a mean change of $19 \%$ with vitamin D supplementation. ${ }^{12}$ Another randomized placebo controlled trial showed that FSI and HOMA-IR significantly decreased by $11.7 \%$ and $12.8 \%$ respectively in vitamin D supplemented group. While, there was a significant increase of $7.8 \%$ in fasting serum insulin and $10 \%$ in HOMA-IR in placebo group $(\mathrm{p}=0.032) .{ }^{31}$ On the contrary, Witham etal did not observe any significant change in serum insulin levels and HOMA-IR with vitamin $\mathrm{D}$ supplementation. ${ }^{32}$ This discrepancy might be because of different dosage and formulation of vitamin $\mathrm{D}$ used and small sample size of the study.

After 12 weeks of vitamin D supplementation in group A, mean percentage reduction in $\mathrm{HbA1c}$ was $11.7 \%, 5.6 \%$ and $5 \%$ in vitamin D "deficient", "insufficient" and "sufficient" subgroups respectively. The mean percentage reduction in HOMA-IR was 36\%, 34.4\% and 32.5\% in vitamin D "deficient", vitamin D "insufficient" and "sufficient" subgroup of patients respectively. On the other hand, in group B vitamin D "deficient" and "insufficient" subgroup of patients showed a mean percentage increase in $\mathrm{HbA} 1 \mathrm{c}$ of $6.9 \%$ and $4.1 \%$ and vitamin D "sufficient" subgroup showed a mean percentage decrease of $0.5 \%$. The mean percentage reduction in HOMA-IR in subgroup of patients in group B was also very less compared to group A. Thus, it proves that adequate vitamin $\mathrm{D}$ levels $(>30 \mathrm{ng} / \mathrm{ml})$ in body were associated with better improvement in $\mathrm{HbA} 1 \mathrm{c}$ and HOMA-IR. There appears to be a relationship between insufficient or deficient vitamin D levels and poor glycaemic control.

Although the reduction in FBG levels was comparable in two groups, the mean percentage reduction in $\mathrm{HbA} 1 \mathrm{c}$ and HOMA-IR levels were more significant $(\mathrm{p}<0.05)$ in group A compared to group B. Many observational and clinical studies have shown that vitamin $D$ dose dependently suppresses the release of pro-inflammatory cytokines (TNF-a, IL-6) which are involved in insulin resistance. Another probable mechanism suggested by various studies is that vitamin $\mathrm{D}$ act on peripheral vitamin $\mathrm{D}$ receptors and increases calcium content of cells, thus promoting glucose transport into peripheral tissues. Other lines of evidence to support the role of vitamin D in diabetes are: (a) presence of specific vitamin $D$ receptors (VDRs) on pancreatic $\beta$-cells (b) the expression of $1-\alpha$ hydroxylase enzyme in pancreatic $\beta$-cells which catalyzes the conversion of 25-hydroxyvitamin $\mathrm{D}$ to 1 , 25dihydroxyvitamin $\mathrm{D}$ (c) presence of a vitamin $\mathrm{D}$ response element in human insulin gene promoter (d) presence of VDR in skeletal muscle. ${ }^{33}$ Thus, the present study demonstrates that addition of vitamin $\mathrm{D}$ to the standard hypoglycaemic agents was more effective in improving long term glycaemic control and insulin sensitivity in type 2 diabetic patients who were having vitamin D deficiency or insufficiency and insulin resistance.

On assessment of adverse effect profile, the patients of both the groups under study tolerated the drugs well and in none of the patients the adverse effects were serious enough to discontinue the drug therapy. In group A, nausea and vomiting occurred in 4 patients, abdominal pain in 2 patients and hypoglycaemia was seen in 3 patients. While in group B only 2 patients reported with nausea and hypoglycaemia. Apart from the above mentioned adverse effects, a very significant $(\mathrm{p}<0.01)$ increase was observed in serum calcium levels in group A. No significant $(p>0.05)$ change was seen in other routine investigations done to monitor vitamin $\mathrm{D}$ toxicity like SGOT, SGPT, ALP and serum phosphorus levels in both the groups.

\section{Limitations}

The limitation of present study was the small sample size with short duration of treatment. Further large sample sized, multi-centric trials with the inclusion of placebo are needed to validate the present findings.

\section{CONCLUSION}

The present study thus concludes that vitamin D therapy added to standard oral hypoglycaemic agents was well tolerated and had shown a more favourable effect on glycaemic control (in terms of reduction in HbAlc levels) and better improvement in insulin resistance (in terms of reduction in insulin levels and HOMA-IR levels) in comparison to standard oral hypoglycaemic agents alone. It demonstrates that supplementation of vitamin D in type 2 diabetic patients who are vitamin $\mathrm{D}$ deficient or insufficient and insulin resistant can enhance insulin sensitivity and improve glycaemic control.

Funding: No funding sources Conflict of interest: None declared

Ethical approval: The study was approved by the Institutional Ethics Committee 


\section{REFERENCES}

1. International Diabetes Federation. IDF Diabetes Atlas, 6th ed. Brussels, Belgium: International Diabetes Federation. 2013.

2. Anjana RM, Pradeepa R, Deepa M, Datta M, Sudha $\mathrm{V}$, Unnikrishnan R. On behalf of the ICMR-INDIAB collaborative study group. Prevalence of diabetes and prediabetes (impaired fasting glucose and/or impaired glucose tolerance) in urban and rural India: Phase I results of the Indian Council of Medical Research-INdia DIA Betes (ICMR-INDIAB) study. Diabetologia. 2011;54:3022-7.

3. Alvin C, David D. Endocrine pancreas and pharmacotherapy of diabetes mellitus and hypoglycemia. In: Laurence L, Bruce A, Bjorn C, eds. Goodman and Gilman's The Pharmacological Basis of Therapeutics. 12th ed. New York: Mc Graw Hill. 2000:1246.

4. Gedik O, Akahn S. Effects of vitamin D deficiency and repletion on insulin and glucagon secretion in man. Diabetologia. 1986;29(3):142-5.

5. Nigil HN, Anton A, John J, Mittal M. Effect of vitamin D supplementation on glycemic control in patients with type 2 diabetes: a systematic review of interventional studies. Journal of Diabetes and Metabolic Disorders. 2015;14:3.

6. Thacher TD, Clarke BL. Vitamin D Insufficiency. Mayo Clinic Proceedings. 2011;86(1):50-60.

7. Bland R, Markovic, Hills CE. Expression of 25 hydroxy vitamin D3-1alpha hydroxylase in the pancreatic islets. J Steroid Biochem Mol Biol. 2004;89-90:121-5.

8. Ritu G, Ajay G. Vitamin D Deficiency in India: Prevalence, Causalities and Interventions. Nutrients. 2014;6:729-75.

9. Kumar S, Davies M, Zakaria Y. Improvement in glucose tolerance and beta-cell function in a patient with vitamin $\mathrm{D}$ deficiency during treatment with vitamin D. Postgraduate Medical Journal. 1994;70(824):440-3.

10. Borissova AM, Tankova T, Kirilov G, Dakovska L, Kovacheva R. The effect of vitamin D3 on insulin secretion and peripheral insulin sensitivity in type 2 diabetic patients. Int J Clin Pract. 2003;57:258-61.

11. Von Hurst PR, Stonehouse W, Coad J. Vitamin D supplementation reduces insulin resistance in South Asian women living in New Zealand who are insulin resistant and vitamin D deficient-a randomised, placebo-controlled trial. Br J Nutr. 2010;103(4):54955.

12. Talaei A, Mohamadi M, Adgi Z. The effect of vitamin $\mathrm{D}$ on insulin resistance in patients with type 2 diabetes. Diabetology \& Metabolic Syndrome. 2013;5:8.

13. Heshmat. Effect of vitamin D on insulin resistance and anthropometric parameters in Type 2 diabetes; a randomized double-blind clinical trial. DARU Journal of Pharmaceutical Sciences. 2012;20:10.
14. Berham D, Trinder P. An improved Color Reagent for the Determination of Blood Glucose by Oxidase System Analyst. 1972;97(151):142-5.

15. Trinder P. Determination of Blood Glucose Using 4aminophanazone as Oxygen Acceptor. J Clin pathol. 1969;22(2):246.

16. Mayer TK. Freedman ZR. Protein Glycosylation in Diabetes Mellitus: A Review of Laboratory Measurements. Clin Chem Acta. 1983;127(2):14784.

17. Peacock I. Glycosylated Haemoglobin: Measurements and Clinical Use. J Clin Pathol. 1984;37(8):841-51.

18. Judzewitsch RG, Pfeifer MA, Best JD, Beard JC, Halter JB, Porte D. Chronic Chlorpropamide therapy of noninsulin-dependent diabetes augments basal and stimulated insulin secretion by increasing islet sensitivity to glucose. J. Clin. End. and Metab. 1982;55:321-8.

19. Kosaka, K, Hagura, R, Kuzuya, T. Insulin responses in equivocal and definite diabetes, with special reference to subjects who had mild glucose intolerance but later developed definite diabetes. Diabetes. 1977;26(10):944-52.

20. Starr J, Mako ME, Juhn D, Rubenstein AH. Measurement of serum proinsulin-like material: cross-reactivity of porcine and human proinsulin in the insulin radioimmunoassay, J. Lab. Clin. Med. 1978;91(4):691-2.

21. Holick MF. Vitamin D Status: Measurement, Interpretation and Clinical Application. Ann Epidemiol. 2009;19(2):73-8.

22. Morris HA. Vitamin D: A Hormone for All Seasons - How much is enough? Understanding the New Pressures. Clin Biochem Rev. 2005;26(1):21-32.

23. Zerwekh JE. Blood biomarkers of vitamin D status. Am J Clin Nutr. 2008;87(4):1087S-91S.

24. De Fronzo RA, Ferranine E. Insulin resistance: a multifaceted syndrome responsible for NIDDM, obesity, hypertension, dyslipidemia and atherosclerotic cardiovascular disease. Diabetes Care. 1991;14:173-94

25. Asemi Z, Karamali M, Esmaillzadeh A. Effects of calcium-vitamin D co-supplementation on glycaemic control, inflammation and oxidative stress in gestational diabetes: a randomised placebocontrolled trial. Diabetologia. 2014;57(9):1798-806.

26. Mohamad MI, El-Sherbeny EE, Bekhet MM. The Effect of Vitamin D Supplementation on Glycemic Control and Lipid Profile in Patients with Type 2 Diabetes Mellitus. J Am Coll Nutr. 2015;21(9):1-6.

27. Sadiya A, Ahmed SM, Carlsson M. Vitamin D supplementation in obese type 2 diabetes subjects in Ajman, UAE: a randomized controlled doubleblinded clinical trial. European Journal of Clinical Nutrition. 2015;69(6):707-11.

28. Tabesh M, Azadbakht L, Faghihimani E, Tabesh M, Esmaillzadeh A. Effects of calcium-vitamin D cosupplementation on metabolic profiles in vitamin D insufficient people with type 2 diabetes: a 
randomised controlled clinicaltrial. Diabetologia. 2014;57(10):2038-47.

29. Bonakdaran S, Hami M, Hatefi A. The effects of calcitriol on albuminuria in patients with type-2 diabetes mellitus. Saudi J Kidney Dis Transpl. 2012;23(6):1215-20.

30. Nasri H, Behradmanesh S, Maghsoudi AR, Ahmadi A, Nasri P, Rafieian-Kopaei M. Efficacy of supplementary vitamin $\mathrm{D}$ on improvement of glycemic parameters in patients with type 2 diabetes mellitus; a randomized double blind clinical trial. Journal of Renal Injury Prevention. 2014;3(1):31-4.

31. Strobel F, Reusch J, Penna-Martinez M, RamosLopez E, Klahold E, Klepzig C. Effect of a randomised controlled vitamin $\mathrm{D}$ trial on insulin resistance and glucose metabolism in patients with type 2 diabetes mellitus. Horm Metab Res. 2014;46(1):54-8.

32. Witham MD, Dove FJ, Dryburgh M, Sugden JA, Morris AD, Strathers AD. The effect of different doses of vitamin $D$ on marker of vascular health in patients of type 2 diabetes. Diabetologia. 2010;53:2112-9.

33. Alvarez JA, Ashraf A. Role of vitamin D in insulin secretion and insulin sensitivity for glucose Homeostasis. Int J Endocrinal. 2010:351-85.

Cite this article as: Dhillon PK, Rai J, Bal BS, Singh NR. A study to assess the effect of vitamin D supplementation on insulin resistance and glycaemic control in type 2 diabetes mellitus patients. Int J Basic Clin Pharmacol 2016;5:466-72. 